\title{
EDITORIAL NOTE \\ Detecting fluoride using a plant species as a bioindicator, evaluating the relationship of endocrine and nerve ganglia in small intestine function, and discovering the effects of protein malnourishment and probiotic supplementation in the digestive system of mammalian models
}

\author{
DIEGO BONATTO and JOÃO ANTONIO PÊGAS HENRIQUES \\ Centro de Biotecnologia, Universidade Federal do Rio Grande do Sul (UFRGS), \\ Avenida Bento Goncalves, 9500, Prédio 43421, Sala 219, Caixa Postal 15005, 91509-900 Porto Alegre, RS, Brasil
}

The study on how the digestive system responds to environmental stimuli and malnourishment is nowadays considered a hot topic of research. Unfortunately the effects of different diets on the intestine morphology and also on its associated systems, such as endocrine and nervous systems, are almost unknown, despite some studies indicate that the microbial composition of mucosal communities in humans can be manipulated through the use of prebiotics (Langlands et al. 2004).

In this present volume two contributions evaluated the effects of severe protein malnutrition and the administration of probiotics on the digestive system of Wistar rats (Rattus norvegicus) (Sant Ana et al. 2012, Lima et al. 2012). Sant'Ana et al. (2012) specifically demonstrated that Wistar rats that received diets with severe protein restrictions display a reduction in the duodenum length, which is an interesting fact per se. However, the same authors also showed that a severe protein restriction diet could lead to the loss of specific neurons associated to digestive systems with an increase in the density of nitrergic neurons. The physiological effects of severe protein restrictions were clearly observed as the animals showed weight and fur loss, as well as diarrhea.

Considering the effects of protein restriction on the digestive system development, Lima et al. (2012) showed that Wistar rats that received a restrictive protein diet together with a probiotic culture did not present a growth deficit of the colon wall strata that generally occurs in malnourished rats especially after lactation. These data indicate that the administration of probiotics during the initial phases of the digestive system development seems to be important to drive the correct functionality of intestine, as also observed by other authors (Preidis et al. 2012).

The study on how the nervous and endocrine systems interact with the small intestine by controlling its functions was addressed by Freitas-Ribeiro et al. (2012) using Didelphis aurita as a model for enteroendocrine cells. The authors demonstrated that the distribution of endocrine and nerve ganglia in the small intestine followed the same morphology encountered in other eutherian mammals.

Another important topic covered by this volume of Annals of the Brazilian Academy of Sciences is the use of fluoride-sensitive species to detect the presence of this halogen in the environment. The work of 
Sant Anna-Santos et al. (2012) described the microscopic effects of fluorine exposition in Spondias dulcis. The authors observed that different concentrations of fluoride caused a rapid development of necroses and induced a leaf abscission in $S$. dulcis, which demonstrated the importance of this plant species for active biomonitoring studies.

\section{REFERENCES}

FreitAs-RibeIRo GM, FonSECA CC, SARTORI SSR, LOURES-RIBEIRo A AND NEVES CA. 2012. Endocrine cells and nerve ganglia of the small intestine of the Opossum Didelphis aurita Wied-Neuwied, 1826 (Mammalia: Didelphidae). An Acad Bras Cienc 84: 747-757.

LANGLANDS SJ, Hopkins MJ, Coleman N AND CUMmings JH. 2004. Prebiotic carbohydrates modify the mucosa associated microflora of the human large bowel. Gut 53: 1610-1616.

Lima DP, De Azevedo JF, Hermes-Uliana C, Alves G, SAnT'Ana DMG and AraúJo EJA. 2012. Probiotics prevent growth deficit of colon wall strata of malnourished rats post-lactation. An Acad Bras Cienc 84: 727-735.

Preidis GA, Saulnier DM, Blutt SE, Mistretta TA, Riehle KP, Major AM, Venable SF, Finegold MJ, Petrosino JF, CONNER ME AND VERSALOVIC J. 2012. Probiotics stimulate enterocyte migration and microbial diversity in the neonatal mouse intestine. FASEB J 26: 1960-1969.

Sant'Ana DMG, ARaújo EJA, Ramos DH, Hermes-Ullana C And Natali MRM. 2012. Characterization of the myenteric neuronal population and subpopulation of the duodenum of adult wistar rat fed with hypoproteic chow. An Acad Bras Cienc 84: 799-806.

SANT'ANNA-Santos BF, AZEVEdo AA, Silva LC ANd Oliva MA. 2012. Diagnostic and prognostic characteristics of phytotoxicity caused by fluoride on Spondias dulcis Forst. F. (Anacardiaceae). An Acad Bras Cienc 84: 689-702. 